\title{
DISAIN PERENCANAAN INSTALASI PENGOLAHAN AIR LIMBAH (IPAL) DAN RE-USE AIR DI LINGKUNGAN PERHOTELAN
}

\author{
Setiyono \\ Pusat Teknologi Lingkungan, BPPTeknologi \\ JI. MH. Thamrin No. 8 Jakarta Pusat
}

\begin{abstract}
Denpasar is one of the number one tourist destination in the world. This city needs a lot of water resources with high quality to meet the needs of the hotel. While the Bali island with a relatively small area can not save the water resources in large numbers, the good management of water resources and efficiency use of water is realy needed. Hotel is one of the largest water users in the city of Denpasar. The water source is from deep ground water and PDAM with the same quality. If someday deficit water and sea water intrusion in Denpasar happened, the hotel will be accused as one major cause of this problem. To overcome these problems, environmentally friendly hotel management will be needed to achieve "GREEN HOTEL \& RESORT" programs in Bali, such as water usage efficiency, water recycle and protect environment from wastewater polution. To achieve this without reducing the amount of water consumption, can be done by using the technology of wastewater reuse, with technology Waste Water Treatment Installation (WWTP) and continued with the water quality improvement technology using multi media filters, ultrafiltration or reverse osmosis.
\end{abstract}

\section{Key words : Hotel yang ramah lingkungan, re-use air limbah}

\section{PENDAHULUAN}

\subsection{Latar Belakang}

Denpasar yang merupakan salah satu daerah tujuan wisata nomor satu di Dunia, membutuhkan sumber daya air dengan jumlah yang sangat besar dan dengan kualitas tinggi. Sementara pulau Bali yang mempunyai luasan sangat terbatas dengan jumlah hutan yang sedikit serta sebagain besar merupakan daerah pantai menyebabkan sedikitnya daerah tangkapan air serta cepatnya air hujan mengalir ke laut. Dengan demikian, maka pulau Bali tidak dapat menyimpan air yang banyak sehingga sangat diperlukan sekali adanya suatu sistem pengelolaan sumber daya air yang optimal serta upaya pemanfaatan air yang effisien. Jika hal ini tidak segera diantisipasi, dikawatirkan semakin cepatnya akan terjadinya intrusi air laut ke daratan. Jika air tanah di daerah wisata ini telah menjadi payau maka tidak mungkin untuk dimanfaatkan lagi sebagai air untuk memenuhi kebutuhan hotel.

Hotel merupakan salah satu pengguna air terbesar di Denpasar. Air diperlukan untuk memenuhi kebutuhan kamar, laundry, kolam renang, kolam ikan \& siram taman serta untuk memenuhi keperluan di dapur. Semua kebutuhan air ini dipenuhi dari air tanah dalam dan dari PDAM dengan kualitas yang sama. Jika suatu saat nanti terjadi defisit air bersih dan intrusi air laut di Denpasar, maka hotel akan dituding sebagai salah satu penyebab utama terjadinya masalah tersebut. Untuk itu diperlukan adanya suatu bentuk pengelolaan hotel yang ramah lingkungan "GREEN HOTEL \& RESORT" dengan suatu bentuk nyata dalam penggunaan sumber daya air yang effisien dan maksimal serta menjaga lingkungannya agar tidak tercemar akibat dari pembuangan limbahnya.

Untuk mewujudkan hal ini tanpa mengurangi jumlah pemakaian air, dapat dilakukan dengan menggunakan teknologi pemanfaatan kembali air limbah, yang saat ini sudah banyak tersedia dengan spesifikasi teknis yang sangat beragam sesuai dengan kualitas hasil yang diinginkan oleh user. Salah satu teknologi yang effisien dan telah banyak diterapkan di Indonesia adalah teknologi Intalasi Pengolahan Air Limbah (IPAL) dengan biofilter anaerob-aerobik dan dilanjutkan dengan teknologi peningkatan kualitas air dengan filter multi media, filter ultra filtrasi atau dengan teknologi reverse osmosis. Semua teknologi ini telah tersedia dan dapat diterapkan dengan baik tinggal kita memilih sesuai dengan kebutuhan kualitas air olahan yang diinginkan.

\subsection{Tujuan Dan Sasaran}

Tujuan dari kegiatan ini adalah membuat disain perencanaan instalasi pengolahan air limbah (IPAL) dan Re-use air di lingkungan perhotelan.

\subsection{Metodologi}


Metodologi pelaksanaan kegiatan ini adalah sebagai berikut:

- Survai lapangan yang dilaksanakan di salah satu hotel di Sanur-Bali.

- Melakukan observasi lapangan dan perencanaan penentuan pengambilan datadata sekunder. Selain itu juga dilakukan perencanaan disain teknis sistem pengolahan air limbah.

- Pengumpulan data, dengan target mendapatkan data-data sebagai berikut:
a. Peta lokasi hotel.
b. Peta pengelolaan air.
c. Jumlah pemakaian air.
d. Peta penyebaran sumber limbah.

- Pengolahan data dan analisis, yaitu dengan melakukan pengolahan data sekunder dan data primer dengan bantuan perangkat lunak basis data dan statistik kemudian hasilnya dianalisa dan dibahas.

\subsection{Hasil Yang Diharapkan}

Hasil yang diharapkan dari pekerjaan ini adalah sebagai berikut :

1. Diperolehnya data tentang sebaran sumber buangan limbah di area hotel.

2. Diperolehnya gambaran tentang rencana penghematan pemakaian air bersih.

3. Diperoleh satu disain perencanaan pengelolaan limbah dan rencana re-use air.

4. Mendapatakan gambaran keuntungan yang akan diperoleh jika melakukan re-use air ini.

\section{HASIL DAN PEMBAHASAN}

\subsection{Kebutuhan Air di Hotel Segara Village}

Berdasarkan hasil survai lapangan dan dilanjutkan diskusi dengan pihak pengelola hotel, diperoleh keterangan tentang pemakaian air di hotel Segara Village. Air ini digunakan untuk memenuhi kebutuhan sebanyak 100 kamar yang ada, laundry, kolam renang, kolam ikan \& siram taman serta untuk memenuhi keperluan di dapur. Untuk memenuhi kebutuhan air tersebut, maka digunakan dua sumber air, yaitu dari air tanah dalam dan dari PDAM. Dari hasil diskusi, diketahui pemakaian air rata-rata per hari adalah sekitar $115 \mathrm{~m}^{3} / \mathrm{hari}$, dengan rincian sebagai berikut :

$\begin{array}{lll}\text { Keb. Air kamar =100 x 0,25 } & =25 & \mathrm{~m}^{3} / \text { hari. } \\ \text { Laundry } & =30 & \mathrm{~m}^{3} / \text { hari. } \\ \text { Kolam renang } & =15 & \mathrm{~m}^{3} / \text { hari. } \\ \text { Dapur dll } & =5 & \mathrm{~m}^{3} / \text { hari. } \\ \text { Air siram taman, kolam } & =40 & \mathrm{~m}^{3} / \text { hari. } \\ \quad \text { TOTAL } & =115 & \mathrm{~m}^{3} / \text { hari. }\end{array}$

\subsection{Jumlah Air Limbah}

Pada umumnya, untuk menentukan jumlah limbah yang dihasilkan didasarkan dari pemakaian air yang berpotensi menjadi limbah. Untuk keperluan domestik pada umumnya jumlah limbahnya sebesar $80-90 \%$ dari pemakaian air yang berpotensi menjadi limbah. Berdasarkan asumsi tersebut, maka jumlah limbah yang dihasilkan oleh hotel Segara Village sebesar :

$\begin{array}{rlrl}\text { Limbah dari kamar } & =100 \times 0,25 & \times 90 \% \\ \text { Limbah laundry } & =22,5 & \mathrm{~m}^{3} / \text { hari. } \\ & =30 \times 90 \% & \\ \text { Limbah dapur dll } & =27 & =5 \times 90 \% & \\ & \mathrm{~m}^{3} / \text { hari. } \\ \text { TOTAL } & =4,5 & \mathrm{~m}^{3} / \text { hari. } \\ & =54 & \mathrm{~m}^{3} / \text { hari. }\end{array}$

Perkiraan jumlah limbah ini akan digunakan sebagai dasar disain IPAL yang direncanakan.

Sumber limbah yang ada dari kamar mandi (grey water), laundry, dapur, dan dari over flow septik tank (black water), air bekas wudlu dan lain-lain menyebar di seluruh area hotel. Saat ini semua limbah tersebut diresapkan ke dalam tanah, dan kalau dibiarkan dalam jangka waktu lama suatu ketika akan mencemari air tanah yang saat ini digunakan untuk memenuhi kebutuhan hotel. Jika hal ini terjadi, maka air tanah tersebut tidak dapat lagi digunakan untuk memenuhi kebutuhan air hotel yang memerlukan air dengan kualitas tinggi. Untuk menghindari hal ini, maka diperlukan sistem penghematan pemakaian air dan sistem pengolahan air limbah yang dapat menghilangkan polutan yang ada sehingga lingkungan tetap terjaga dengan baik. IPAL yang dilengkapi dengan re-use ini ternyata dapat menjawab dan menyelesaikan kedua persoalan tersebut sekaligus, dimana sistem IPAL akan mendegradasi polutan yang ada sehingga akan menjaga lingkungan dari bahaya pencemaran dan sistem re-use akan mensuplay air untuk kebutuhan lain sehingga akan terjadi penghematan pemakaian air.

\subsection{Sistem Pengumpulan Air Limbah}

Karena di hotel Segara Village hanya tersedia satu calon lokasi IPAL yang sesuai, maka pengolahan limbah hotel Segara Village ini akan menggunakan sistem terpusat. Untuk itu diperlukan satu sistem yang dapat menyalurkan semua limbah yang ada menuju lokasi IPAL. Karena area hotel yang sangat luas $( \pm 6 \mathrm{Ha})$ dan datar serta sumber limbah saat ini berada di tengah-tengah taman yang sudah tertata rapi, 
maka diperlukan suatu sistem yang tidak sederhana. Agar sistem dapat berjalan dengan baik, sesuai dengan rencana yang diinginkan serta tidak mengganggu secara estitika dan keindahan, maka diperlukan perencanaan jaringan yang tepat sesuai dengan tempat tersebut. Ada dua alternatif sistem pengumpulan limbah yang dapat dikerjakan serta jenis dan sumber limbah yang akan diolah di IPAL ini nanti. Gambar 1 menunjukkan sistem pengumpulan limbah dari sumbernya.

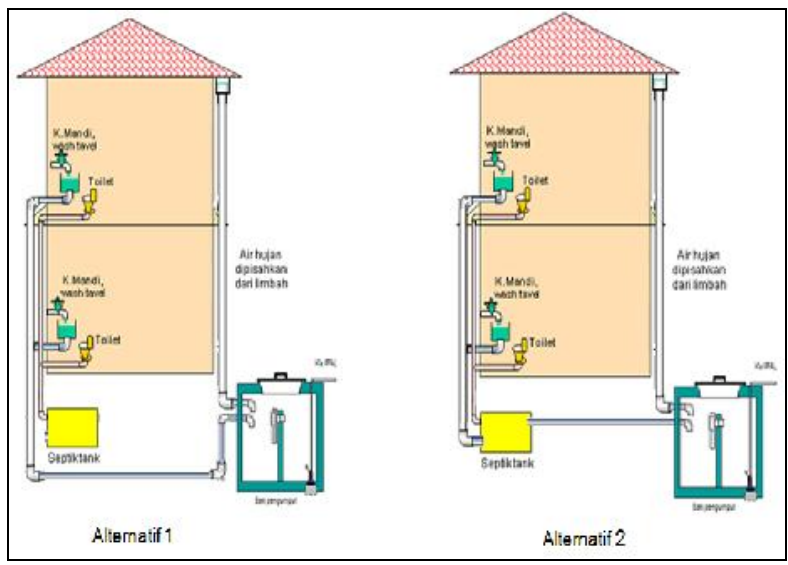

Gambar 1 : Alternatif pengumpulan limbah dari sumbernya.

\section{Keterangan :}

- Alternatif 1 : hanya limbah dari kamar mandi (grey water) yang akan diolah di IPAL, sedangkan limbah toilet (black water) tetap diresapkan ke dalam tanah.

- Alternatif 2 : semua limbah dari kamar mandi (grey water \& black water) diolah di IPAL, dengan sistem dikumpulkan di bak pengumpul terlebih dahulu.

Mengingat lokasi kerja yang sangat luas dan terbuka sehingga resiko tercampurnya limbah dengan air hujan sangat besar serta area kerja yang datar dan di taman, maka dipilihlah sistem pengumpulan limbah dengan menggunakan pemompaan dengan perpipaan tertutup. Sistem ini dibuat dengan cara mengumpulkan limbah dari setiap sumber ke dalam bak pengumpul. Limbah yang terkumpul dalam bak pengumpul ini akan dipompa secara otomatis menggunakan pompa submersible yang dilengkapi dengan level kontrol. Untuk sumber limbah yang sangat jauh dari lokasi IPAL, maka dilakukan dengan sistem transfer dimana limbah dari bak pengumpul dipompa ke dalam bak transfer yang berfungsi sebagai bak transfer ke lokasi IPAL. Kemudian limbah yang terkumpul dalam bak transfer ini dipompa lagi menuju IPAL. Secara detil sistem jaringan pengumpulan limbah ini dapat dilihat seperti pada Lampiran 1.
Karena lokasi jaringan yang berada di tengah taman hotel, maka untuk menyalurkan limbah ini menuju ke IPAL perlu direncanakan jalur yang aman serta tidak mengganggu estetika dan keindahan.

\subsection{Teknologi IPAL Yang Digunakan}

Dalam menentukan teknologi proses pengolahan air limbah Hotel Segara Village, didasarkan atas beberapa kriteria antara lain :

- Efisiensi pengolahan dapat mencapai standar Baku Mutu Lingkungan,

- Pengelolaannya harus mudah,

- Lahan yang diperlukan tidak terlalu besar,

- Konsumsi energi sedapat mungkin rendah,

- Biaya operasinya rendah,

- Lumpur yang dihasilkan sedapat mungkin kecil,

- Dapat digunakan untuk air limbah dengan beban BOD yang cukup besar,

- Dapat menghilangkan padatan tersuspensi (SS) dengan baik,

- Perawatannya mudah dan sederhana.

Berdasarkan kriteria tersebut di atas untuk pengolahan air limbah Hotel Segara Village yang tepat digunakan adalah kombinasi proses biofilter anaerob-aerob. Skema proses biofilter anaerob-aerob seperti diperlihatkan pada Lampiran 2 \& 3.

\subsection{Uraian Proses Ipal \& Sistem Re-Use}

\subsubsection{Proses Pengolahan Limbah di IPAL}

Air limbah domestik yang akan diolah di IPAL berasal dari laundry, kamar mandi, wastafel, limpasan septik tank dan dari kantin. Diagram proses pengaliran air limbah menuju IPAL seperti ditunjukkan pada Lampiran Gambar 2. Air limbah dari beberapa sumber ditampung dalam suatu bak penampung/pengumpul. Dari bak pengumpul, air limbah dialirkan dengan pompa celup menuju ke IPAL yang lokasinya terletak di samping lapangan tenis.

Pertama air limbah dari bak-bak pengumpul dipompa menuju ke bagian pemisah lemak minyak untuk dipisahkan sisa lemak dan juga kotoran melayang yang tidak terpisahkan dalam bak pengumpul. Selanjutnya dari pemisah lemak melimpas ke bak equalisasi. Equalisasi ini berfungsi untuk menampung air limbah sementara dan mengatur debit air menuju ke IPAL. Pengaturan debit ke IPAL dilakukan dengan pompa celup (submersible pump).

Di dalam unit IPAL, pertama air limbah dialirkan masuk ke bak pengendap awal, untuk mengendapkan partikel lumpur, pasir dan kotoran organik tersuspensi. Selain sebagai bak pengendapan, juga berfungsi sebagai bak 
pengurai senyawa organik yang berbentuk padatan, sludge digestion (pengurai lumpur) dan penampung lumpur.

Air limpasan dari bak pengendap awal selanjutnya dialirkan ke bak kontaktor anaerob (biofilter Anaerob) dengan arah aliran dari atas ke bawah. Di dalam bak kontaktor anaerob tersebut diisi dengan media khusus dari bahan plastik tipe sarang tawon. Jumlah bak kontaktor anaerob terdiri dari dua buah ruangan. Penguraian zat-zat organik yang ada dalam air limbah dilakukan oleh bakteri anaerobik atau fakultatif aerobik. Setelah beberapa hari operasi, pada permukaan media filter akan tumbuh lapisan film mikroorganisme. Mikroorganisme inilah yang akan menguraikan zat organik yang belum sempat terurai pada bak pengendap.

Air limbah dari bak kontaktor (biofilter) anaerob dialirkan ke bak kontaktor aerob. Di dalam bak kontaktor aerob ini diisi dengan media khusus dari bahan plastik tipe sarang tawon, sambil diaerasi atau dihembus dengan udara sehingga mikroorganisme yang ada akan menguraikan zat organik yang ada dalam air limbah serta tumbuh dan menempel pada permukaan media. Dengan demikian air limbah akan kontak dengan mikroorgainisme yang tersuspensi dalam air maupun yang menempel pada permukaan media yang mana hal tersebut dapat meningkatkan efisiensi penguraian zat organik, serta mempercepat proses nitrifikasi, sehingga efisiensi penghilangan ammonia menjadi lebih besar. Proses ini sering di namakan Aerasi Kontak (Contact Aeration).

Dari bak aerasi, air mengalir ke bak pengendap akhir. Di dalam bak ini lumpur aktif yang mengandung mikroorganisme diendapkan dan sebagian air dipompa kembali ke bagian bak pengendap awal dengan pompa sirkulasi lumpur. Debit pompa sirkulasi ini dapat diatur dengan buka tutup kran.

Sebagian air di bak pengendap akhir melimpas (outlet/over flow) melalui weir menuju ke bak penampung sementara melewati flow meter di luar IPAL. Dari bak penampung outlet sementara ini air dialirkan menuju ke kolam ikan sebagai bio indikator dan selanjutnya menuju bak penampungan sementara sebelum dilakukan proses peningkatan kualitas dengan unit multimedia filtrasi.

\subsubsection{Pengolahan Secara Filtrasi}

Tujuan penyaringan adalah untuk memisahkan padatan tersuspensi dari dalam air yang diolah. Pada penerapannya filtrasi digunakan untuk menghilangkan sisa padatan tersuspensi yang tidak terendapkan pada proses sedimentasi. Pada pengolahan air buangan, filtrasi dilakukan setelah pengolahan kimia-fisika atau pengolahan biologi. Ada dua jenis proses penyaringan yang umum digunakan, yaitu penyaringan lambat dan penyaringan cepat. Penyaringan lambat adalah penyaringan dengan memanfaatkan energi potensial air itu sendiri, artinya hanya melalui gaya gravitasi. Penyaringan ini dilakukan secara terbuka dengan tekanan atmosferik. Sedangkan penyaringan cepat adalah penyaringan dengan menggunakan tekanan yang melebihi tekanan atmosfir, biasanya dengan menggunakan pompa, seperti yang akan diterapkan di sistem re-use hotel Segara Village ini.

Berdasarkan jenis media filter yang digunakan, penyaringan dapat digolongkan menjadi dua jenis, yaitu filter media granular (butiran) dan filter permukaan. Pada jenis media granular, media yang paling baik mempunyai karakteristik sebagai berikut: Ukuran butiran membentuk pori-pori yang cukup besar agar partikel besar dapat tertahan dalam media, sementara butiran tersebut juga dapat membentuk pori yang cukup halus, sehingga dapat menahan suspensi. Butiran media bertingkat, sehingga lebih efektif pada saat proses pencucian balik (backwash). Saringan mempunyai kedalaman yang dapat memberikan kesempatan aliran mengalir cukup panjang. Sejauh ini media yang paling baik adalah pasir yang ukuran butirannya hampir seragam dengan ukuran antara 0,6 hingga 0,8 $\mathrm{mm}$.

Laju operasi untuk penyaringan ditentukan oleh kualitas air baku dan media filter. Pada umumnya laju penyaringan pada saringan pasir cepat adalah 82,4 liter per menit $/ \mathrm{m}^{2}$. Sistem yang ada pada saat ini dapat menaikkan aliran hingga 206 liter per menit/m². Unggun saringan yang terdiri dari dua jenis media, yaitu arang dan pasir menghasilkan lapisan media arang yang butirannya besar (berat jenis 1,4-1,6) berada diatas media pasir yang lebih halus (berat jenis 2,6). Susunan media dari atas ke bawah kasarhalus, akan memudahkan aliran air. Flok yang besar akan tertahan butiran arang di bagian atas/permukaan unggun.

\subsubsection{Pengolahan Secara Adsorpsi}

Adsorpsi adalah penumpukan materi pada interface antara dua fase. Pada umumnya zat terlarut terkumpul pada interface. Proses adsorpsi memanfaatkan fenomena ini untuk menghilangkan materi dari cairan. Banyak sekali adsorbent yang digunakan di industri, namun karbon aktif merupakan bahan yang sering digunakan karena harganya murah dan sifatnya nonpolar. Adsorbent polar akan menarik air sehingga kerjanya kurang efektif. Pori-pori pada karbon dapat mencapai ukuran 10 angstrom. Total luas permukaan umumnya antara 500 - 
$1500 \mathrm{~m}^{2} / \mathrm{gr}$. Berat jenis kering lebih kurang 500 $\mathrm{kg} / \mathrm{m}^{3}$.

\subsubsection{Sistem Kelistrikan IPAL}

Peralatan dan Mesin di IPAL dan system Re-use meliputi pompa feed air limbah di bak equalisasi, pompa sirkulasi air limbah, blower udara, pompa feed sistem re-use air dan dosing klorin. Semua peralatan dan mesin di IPAL ini dioperasikan dan dikontrol melalui satu sistem di panel kontrol IPAL. Sedangkan pompa-pompa di masing-masing bak pengumpul dipasang dan dikontrol secara terpisah dari IPAL. Gambar 2 menunjukkan Wire diagram kelistrikan tersebut.

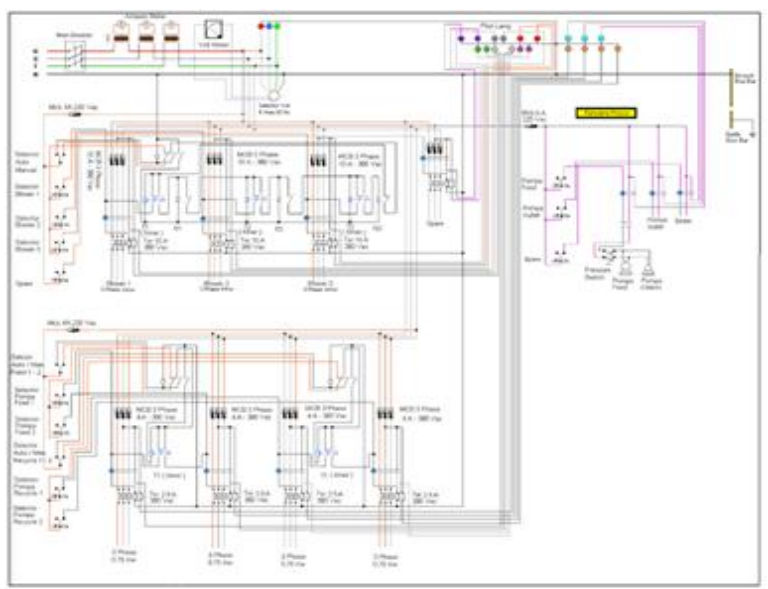

Gambar 2 : Wire diagram kelistrikan IPAL dan Re-use

\subsection{Calon Lokasi Untuk IPAL}

IPAL dan sistem re-use air limbah hotel Segara Village dengan kapasitas $60 \mathrm{~m}^{3} /$ hari rencananya akan ditempatkan di ujung lapangan tenis. Saat ini lokasi tersebut merupakan lahan kosong yang belum termanfaatkan dengan luas area yang dapat digunakan seluas $8 \times 15 \mathrm{~m}$. Secara detail lay out dan foto lokasi tersebut ditunjukkan pada gambar $3 \& 4$.

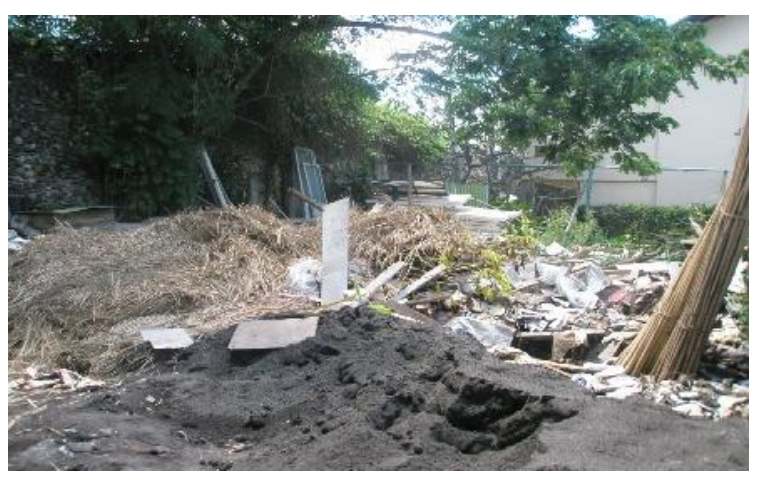

Gambar 3 : Foto calon lokasi IPAL yang direncanakan.

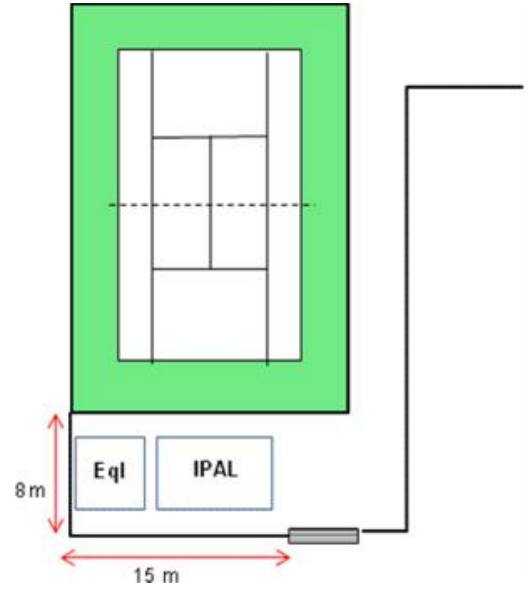

Gambar 4 : Denah calon lokasi IPAL yang direncanakan.

\subsection{PERKIRAAN BIAYA OPERASIONAL DAN EFFISIENSI YANG DIPEROLEH}

\subsubsection{Biaya Operasional IPAL \& Re-use}

Biaya operasional dari instalasi pengolahan limbah dan sistem re-use ini terdiri dari biaya listrik untuk pompa dan blower, biaya perawatan peralatan dan mesin dan biaya tenaga operator. Secara rinci jumlah biaya operasional IPAL tersebut adalah :

\section{a. Kebutuhan listrik}

\begin{tabular}{|c|l|c|c|c|}
\hline NO & PERALATAN & $\begin{array}{c}\text { LISTRIK } \\
\text { (WATT) }\end{array}$ & $\begin{array}{c}\text { JAM OPERASI } \\
\text { per HARI }\end{array}$ & $\begin{array}{c}\text { JUMLAH } \\
\text { KWH / HARI }\end{array}$ \\
\hline 1 & $\begin{array}{l}\text { Pompa Air } \\
\text { Equalisasi }\end{array}$ & 250 & 24 & 6 \\
\hline 2 & Pompa Sirkulasi & 250 & 24 & 6 \\
\hline 3 & Pompa re-use & $2 \times 250$ & 8 & 4 \\
\hline 4 & Blower Udara & $4 \times 100$ & 24 & 9,6 \\
\hline \multicolumn{4}{|c|}{ TOTAL } & $\begin{array}{c}25,6 \\
\text { Kwh/hari }\end{array}$ \\
\hline
\end{tabular}

b. Biaya Perawatan sekitar Rp 600.000 ,-/bln.

c. Tenaga operator IPAL : orang, Rp 1.250 .000 / orang / bulan

Total Biaya Operasional IPAL:

\begin{tabular}{|c|l|c|c|c|}
\hline NO & JENIS BIAYA & $\begin{array}{c}\text { JUMLAH } \\
\text { UNIT }\end{array}$ & SATUAN & $\begin{array}{c}\text { TOTAL BIAYA } \\
\text { IHARI }\end{array}$ \\
\hline 1 & $\begin{array}{l}\text { Total biaya } \\
\text { listrik }\end{array}$ & $25,6 \mathrm{Kwh}$ & $\begin{array}{c}\text { Rp. } 500 \\
\text { /Kwh }\end{array}$ & Rp. 12.800 \\
\hline 3 & $\begin{array}{l}\text { Biaya } \\
\text { perawatan }\end{array}$ & 2 org & $\begin{array}{l}\text { Rp. } \\
1.250 .000 \\
\text { /org/bulan }\end{array}$ & Rp. 83.333 \\
\hline 2 & $\begin{array}{l}\text { Biaya tenaga } \\
\text { kerja 2 orang } \\
\text { operator }\end{array}$ & TOTAL & Rp. 116.133/hari \\
\hline \multicolumn{3}{|c|}{} \\
\hline
\end{tabular}


Dari total biaya operasional IPAL ini dapat dihitung juga besarnya biaya operasional untuk pengolahan limbah setiap meter kubiknya, yaitu sebagai berikut :

- Jumlah air limbah per hari $\quad=54 \mathrm{~m}^{3}$

- Biaya pengolahan air limbah

$=$ Rp.116.133/54 $\mathrm{m}^{3}$, atau

$=R p 2.150 / \mathrm{m}^{3}$ limbah.

\subsubsection{Efisiensi Yang Diperoleh}

Effisiensi yang diperoleh dari sistem reuse ini diperoleh dari besarnya nilai rupiah dari jumlah air yang dapat dihemat karena digantikan oleh air olahan IPAL ini. Secara rinci jumlah effisiensi yang diperoleh adalah sebagai berikut :

$=($ Jumlah air yang di re-use $x$ Harga air $)-$ Biaya Operasional IPAL

$=\left(54 \mathrm{~m}^{3} /\right.$ hari $x$ Rp.22.000/m³) - Rp.116.133,/hari

$=$ Rp. $1.188 .000-$ Rp. 116.133,- / hari

$=$ Rp. 1.071.867 / hari.

$=$ Rp. 32.156.010/bulan.

= Rp. 385.872.120/tahun.

\section{KESIMPULAN}

Berdasarkan hasil analisis tersebut $\mathrm{d}$ atas, maka dapat ditarik beberapa kesimpulan, antara lain :

- Rencana pengelolaan limbah dengan teknologi IPAL dan dilanjutkan dengan Reuse air akan dapat digunakan sebagai solusi permasalahan bahaya pencemaran lingkungan dan menghindari terjadinya defisit air bersih.

- Teknologi re-use dapat menghemat pemakaian air bersih, tanpa mengurangi jumlah pemakaian air. Program ini dapat menghemat pemakaian air sampai dengan $50 \%$.

- Ada banyak keuntungan yang akan diperoleh oleh pengelola hotel jika gerakan "Green Hotel \& Resort" (upaya pemanfaatan kembali air) ini dilakukan antara lain :

1. Akan meningkatkan image di masyarakat sekitar dan internasional sehingga akan meningkatkan tingkat hunian hotel.

2. Menghindari ternyadinya konflik sosial dengan masyarakat di sekitar karena persoalan kekurangan air bersih dan pencemaran lingkungan.

3. Menghindari terjadinya kerusakan lingkungan (intrusi air laut, penurunan muka daratan akibat penyedotan air bawah tanah)

4. Memberikan lapangan kerja bagi operator IPAL,

5. Mendapatkan keuntungan finasial, karena penurunan pajak pemakaian air.

6. Sebagai hotel yang pertama kali berpredikat "Green Hotel", maka Segara Village akan menjadi pioneer di bidang pengolahan air limbah dan akan dipublikasikan secara luas oleh berbagai media.

\section{DAFTAR PUSTAKA}

1. Adriaens, P., Kohler, HP.E, Kohler-Staub, D., and Focht, D.D. (1989). Bacterial dehalogenation of Chlorobenzoates and coculture biodegradation of 4,4dichlorobiphenyl. Appl. Environ. Microbiol. 5:887-892.

2. BPPT, (2002). Laporan akhir kegiatan "Pengkajian Teknologi Pengolahan Air Limbah Industri Kecil Pelapisan Logam". Pusat Pengkajian dan Penerapan Teknologi Lingkungan (P3TL) - BPPT.

3. Chaney, R.L. 1980. Health Risks Assosiated with Toxic Metals in Minicipal Sludge, pp. 5973. In G. Bitton, B.L Risk of land Application. Proc. Ann Arbor Science Publisher, Inc. Michigan.

4. Forstner, W. 1978. Metal Pollution in the Aquatic Environment. Applied Science Publisher Ltd.

5. Overcash, M.R. (1981). Decomposition of Toxic and Nontoxic Organic Compounds in Soils. Ann Arbor Science Publishers Inc./The Butterworth Group, Michigan USA.

6. Raka, I G., Zen, M.T., Soemarwoto, O., Djajadiningrat, S.T., and Saidi, Z. (1999). Paradigma Produksi Bersih: mendamaikan pembangunan ekonomi dan pelestarian lingkungan. Penerbit Nuansa, Bandung, Indonesia

7. Setiyono (2002). Sistem Pengelolaan Limbah B-3 di Indonesia. Kelompok Teknologi Air Bersih dan Limbah Cair, Pusat pengkajain dan Penerapan teknologi Lingkungan (P3TL), Deputi Bidang Teknologi Informasi, Energi, Material dan Lingkungan, Badan Pengkajain dan Penerapan Teknologi (BPPT).

8. Sommers, L.E. 1980. Toxic Metals in Agricultural Crops, pp. 105-131. In G. Bitton, B.L. Damron, G. T. Edds and J.M. Davidson; ed. Sludge: Health isk of Land Application. 
Proc. Ann. Arbor Science Publisher, Inc. Michingan.

9. Stoewsand, G. S. 1986. Trace Metal Problems with Industrial Waste Materials Applied to Vegetable Producing Soils, pp. 423-439. In H.D. Graham, ed. The Safety of Foods, 2nd Edition. AVI Publishing Company; Inc. Wesport, Connecticut.

10. Suffet, I.H. (1977). Fate of Pollutants in the Air and Water Environments. Volume 8, Part 1, "Mechanism of interaction between environments and mathematical modeling and the physical fate of pollutants. Advances in Environmental Science and Technology. John Wiley \& Sons, A Wiley-Interscience Publications, New York, USA.

11. (1977). Fate of Pollutants in the Air and Water Environments. Volume 8. Part 2, "Chemical and biological fate of pollutants in the environment". Advances in Environmnetal Science and Technology. John Wiley \& Sons, A Wiley-Interscience Publications, New York, 


\section{LAMPIRAN 1}

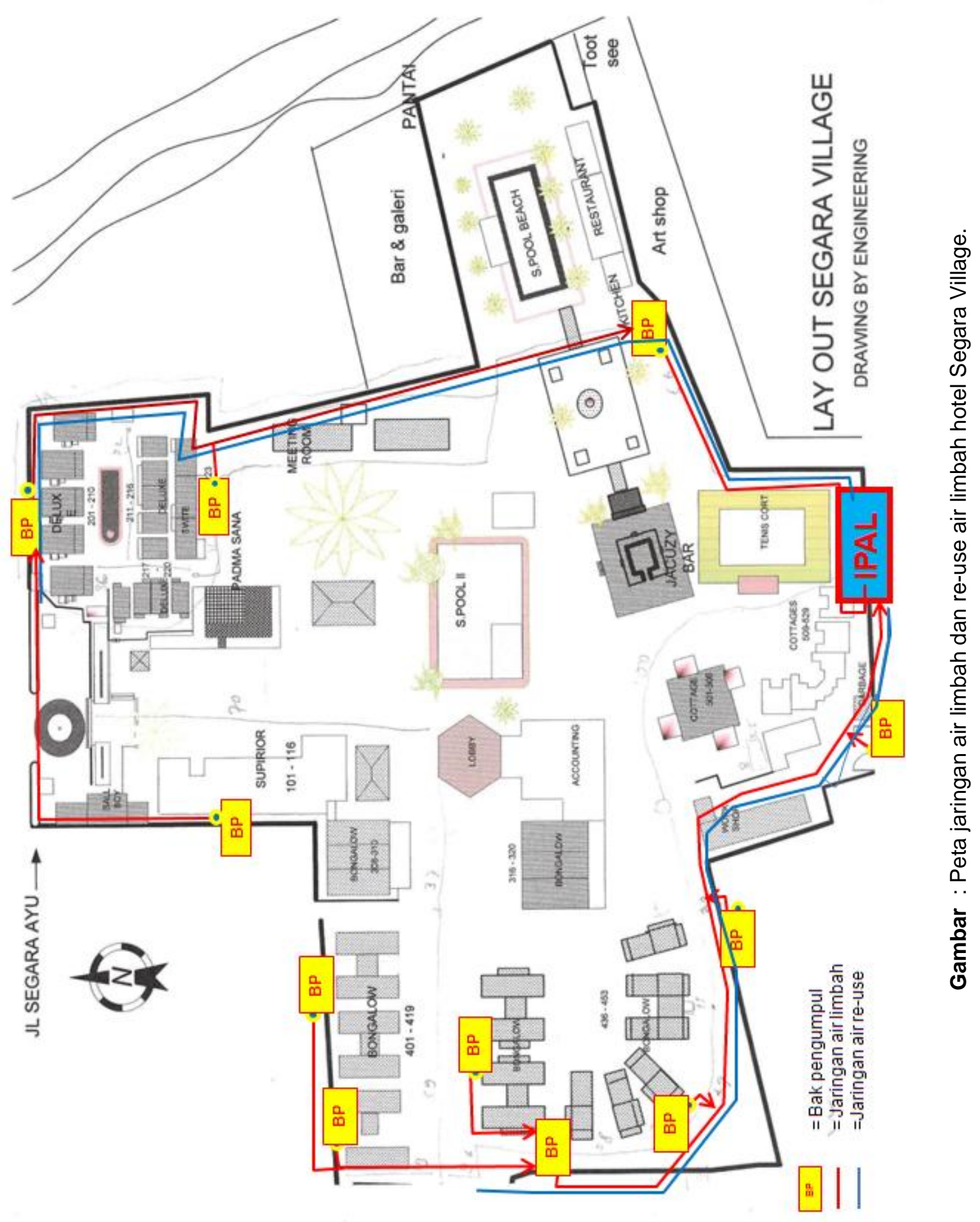




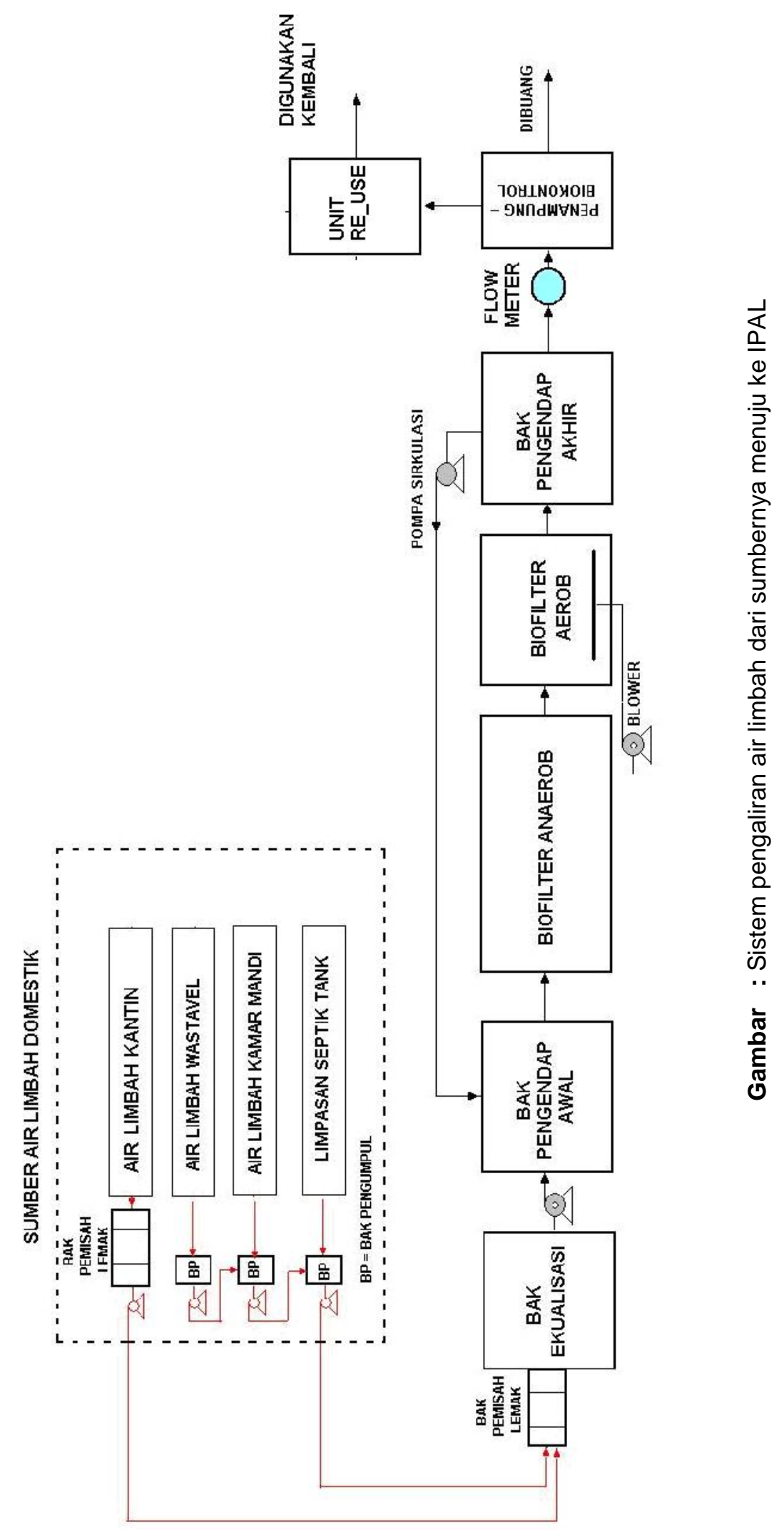




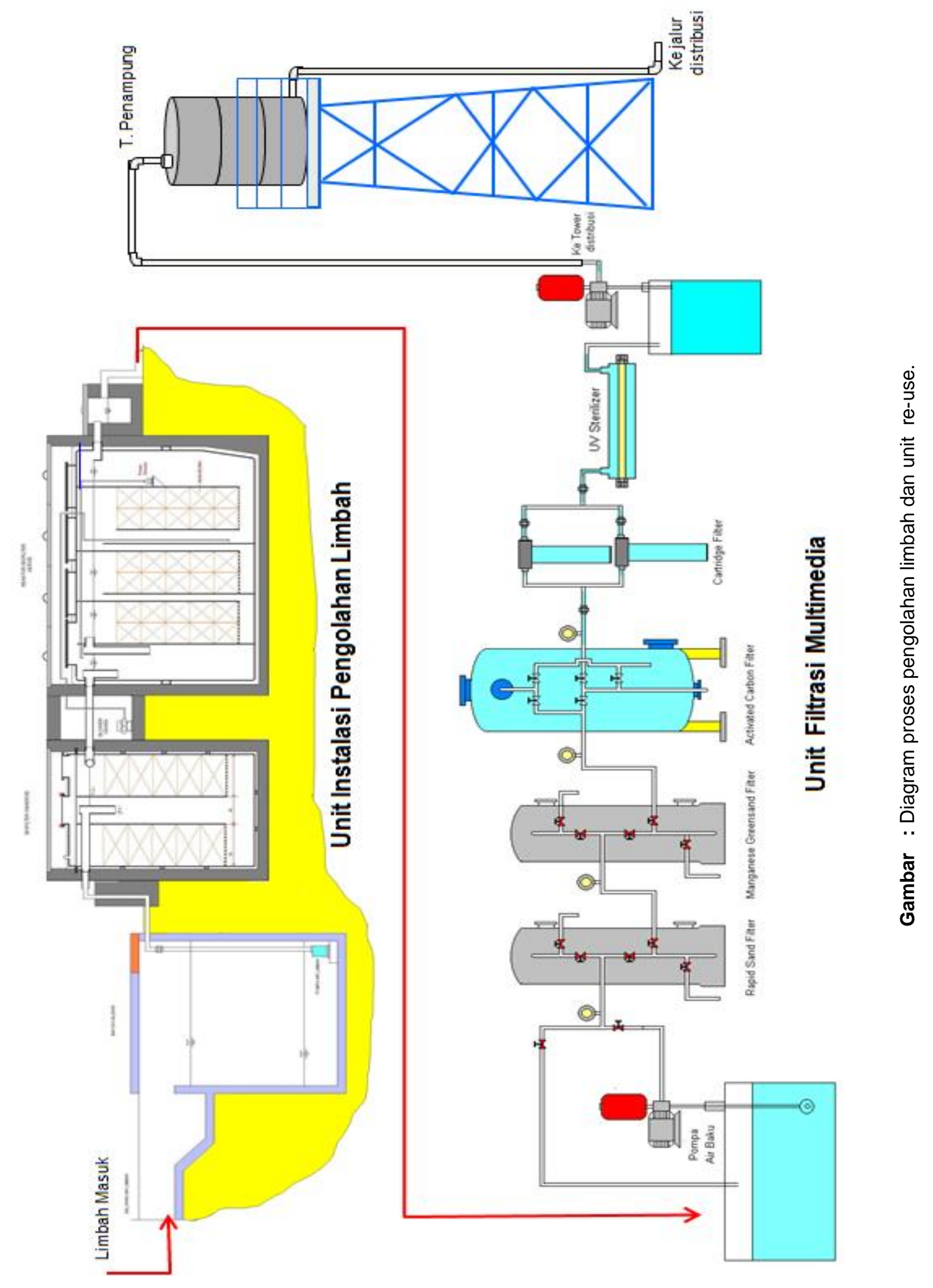


Denpasar yang merupakan salah satu daerah tujuan wisata nomor satu di Dunia membutuhkan sumber daya air dengan jumlah yang sangat besar dan dengan kualitas yang tinggi untuk memenuhi kebutuhan hotel. Sementara Pulau Bali dengan area yang relative kecil tidak dapat menyimpan sumber daya air dalam jumlah besar, sehingga diperlukan suatu slstem pengelolaan sumber daya air yang baik dan pemanfaatan air yang effisien. Hotel merupakan salah satu pengguna air terbesar di Denpasar memenuhi kebutuhan airnya dari sumber air tanah dalam dan dari PDAM dengan kualitas yang sama. Jika suatu saat nanti terjadi defisit air bersih dan intrusi air laut di Denpasar, maka hotel akan dituding sebagai salah satu penyebab utama terjadinya masalah tersebut. Untuk itu diperlukan adanya suatu bentuk pengelolaan hotel yang ramah lingkungan "GREEN HOTEL \& RESORT" dengan suatu bentuk nyata dalam penggunaan sumber daya air yang effisien dan maksimal serta menjaga lingkungannya agar tidak tercemar akibat dari pembuangan limbahnya. Untuk mewujudkan hal ini tanpa mengurangi jumlah pemakaian air, dapat dilakukan dengan menggunakan teknologi pemanfaatan kembali air limbah, dengan teknologi Intalasi Pengolahan Air Limbah (IPAL) dan dilanjutkan dengan teknologi peningkatan kualitas air dengan filter multi media, filter ultra filtrasi atau dengan teknologi reverse osmosis.

Denpasar is one of the number one tourist destination in the world. This city needs a lot of water resources with high quality to meet the needs of the hotel. While the Bali island with a relatively small area can not save the water resources in large numbers, the good management of water resources and efficiency use of water is realy needed. Hotel is one of the largest water users in the city of Denpasar. The water source is from deep ground water and PDAM with the same quality. If someday deficit water and sea water intrusion in Denpasar happened, the hotel will be accused as one major cause of this problem. To overcome these problems, environmentally friendly hotel management will be needed to achieve "GREEN HOTEL \& RESORT" programs in Bali, such as water usage efficiency, water recycle and protect environment from wastewater polution. To achieve this without reducing the amount of water consumption, can be done by using the technology of wastewater reuse, with technology Waste Water Treatment Installation (WWTP) and continued with the water quality improvement technology using multi media filters, ultrafiltration or reverse osmosis. 